\title{
SHAPING A PARAGON OF THE PURITAN FEMALE IMAGE: MARY ROWLANDSON'S CAPTIVITY NARRATIVE
}

\section{LIPING ZHENG}

John F. Kennedy Institute for North American Studies, Free University of Berlin, Germany

\begin{abstract}
Captivity narratives play an enduring role in the documentation of the early colonial history of America. Concerning this popular literary genre emerging in the seventeenth Century, Mary Rowlandson's best-seller "A Narrative of the Captivity and Restoration of Mrs. Mary Rowlandson (1682)" is a classic example of captivity narratives in American early literature. Simultaneously, it marks the new beginning of women literature in American literary history. This work narrates the woman writer's true experience with American Indians during the King Philip's War in 1676. This article argues that Rowlandson's autobiographical writing attempts to shape herself as a role model for the Puritan women who bravely confronted an unprecedented life predicament in New England of the tumultuous colonial period. It examines how Rowlandson's great female image is vividly molded in five respects: the captivity narrative's publication, declaration of her chastity, religious piety, a capability Puritan woman, and captive's metamorphosis. From her female perspective, Rowlandson creates a paragon of Puritan women, who survives the captivity by exerting her extraordinary virtues and merits.

KEYWORDS: Captivity Narrative, Female Image, Puritan Women \& Mary Rowlandson
\end{abstract}

Received: Oct 18, 2017; Accepted: Nov 08, 2017; Published: Jan 30, 2018; Paper Id.: IJELFEB201811

\section{INTRODUCTION}

The captivity narrative of Mary Rowlandson has generally been regarded as a marvelous example of American frontier literature. The book A Narrative of the Captivity and Restoration of Mrs. Mary Rowlandson (also known as The Sovereignty and Goodness of God) written by the New England housewife in1682, recounts her true captivity experience during the King Philip's War (or Metacom's war) in 1676. Since its publication in 1682, the little book has gone through almost forty editions. Rowlandson's narrative, as well as that of Jonathan Dickenson, is "in the pattern of the best known of the narratives" (Pearce 3). While she offers the reader an insight into the significant historical event, the writer recounts a successful legendary adventure story of how she managed to survive in unimaginably harsh circumstances in captivity. The fresh, plain language, the vivid description, unswerving faith and unaffected feelings all contribute to an impressive Puritan feminine image. Although three centuries have gone by, Rowlandson's work still strikes contemporary readers and continues to be influential in literal, historical, and cultural studies.

The uniqueness of A Narrative of the Captivity and Restoration of Mrs. Mary Rowlandson is the author's feminine perspective, which is considerably rare in colonial literature. Like literal scholars Lisa Logan, Steven Neuwirth, and Margaret H. Davis, this article also focuses on the issue of femininity predominantly represented in the captivity narrative. While Logan explores the literal and figurative spaces such as home and wilderness and the positions of women as different subjects within the text, Neuwirth works on the disjuncture of masculine and 
feminine voices and the different ideologies they articulate, and Davis probes Rowlandson's self-perception as a virtuous Puritan goodwife, the study explores the ways Rowlandson shapes her image as a Puritan female paragon. Presenting more than a gruesome tale of an Indian captive, the first-person narrative reveals the heroine's courage, wisdom, chastity, shrewdness, and capability, most virtues a female Puritan role model is supposed to own. The great appeal of it is represented in the process of her dramatic metamorphosis from a desperate captive to a strong-willed woman. From being lost to being redeemed, in different roles-woman, captive, author, wife, mother, neighbor, Puritan, Rowlandson positions herself so well that she becomes a representative image in the history of American early literature. Therefore, this essay examines how Rowlandson's great feminine image is molded in five respects: publication, chastity, piety, capability, and metamorphosis.

\section{THE PUBLICATION OF ROWLANDSON'S CAPTIVITY NARRATIVE}

You have stepped out of your place. You have rather been a Husband than a Wife and a Preacher than a Hearer; and a Magistrate than a Subject....

Thomas Prince to Anne Hutchinson (cited in Hall 383)

In order to decipher Mary Rowlandson, we should unquestionably first take into account her role as a woman writer. Anne Hutchinson, another rarely prominent Puritan female in the seventeenth century, suffered a miserable fate. Because of her gender, her dissident religious ideas, and the threat arising from her strong sway force of the major power in the male-centered Puritan community, she was brought to trial, convicted, and eventually banished from the Massachusetts Bay Colony. Women were not supposed to be active outside the domestic purview, and their voice was severely restricted, or even forbidden. Even if they were encouraged to speak or write, the mere reason was for the learning of scriptures. The cited remarks of Governor John Winthrop offer historical evidence of the Puritan power's excoriation for women's pursuit of literacy. In 1645, Winthrop wrote in his journal-history as follows:

Mr. Hopkins, the governor of Hartford upon Connecticut, came to Boston, and brought his wife with him, (a godly young woman, and of special parts,) who was fallen into a sad infirmity, the loss of her understanding and reason, which had been growing upon her divers years, by occasion of her giving herself wholly to reading and writing, and had written many books. Her husband, being very loving and tender of her, loathed to grieve her; but he saw his error when it was too late. For if she had attended to her household of fairs, and such things as belong to women, and not gone out of her way and calling to meddle in such things as are proper for men, whose minds are stronger, she had kept her wits, and might have improved them usefully and honorably in the place God had set her (cited in Howe 108).

It is very obvious that Winthrop declared his strong objection to the reading and writing of Mr. Hopkins' wife. In his view, writing leads to her "infirmity" which means "the loss of her understanding and reason, which sounds similar to a ridiculous old Chinese saying that a woman's ignorance is her virtue. This woman is thought to be not only neglectful of her regular domestic duties, but also defy God's arrangement for "the weaker sex", which means that only men have the right to read and write. Likewise, Thomas Parker harshly criticized her own sister's act of publication, "Your printing of a Book, beyond the custom of your Sex, doth rankly smell" (cited in Logan 260). From his extremely offensive words, we observe that gender plays an important role with regard to publication. According to Winthrop and Parker, both body and mind of women are inferior to those of men. However, when Mary Rowlandson's captivity narrative came out approximately three decades later, her book gained a large audience, and its widespread popularity made it even a best- 
seller. One cannot help asking why she was so lucky that she was not reprimanded for such an audacious act.

The answer lies in the preface and appended sermon written by two influential Puritan ministers, Increase Mather and Joseph Rowlandson, the latter of whom was Mary Rowlandson's husband. Without their encouragement, support, and sanction, Rowlandson's striking narrative, possibly could not have any chance to be published in the seventeenth-century historical context. Here let us take a closer look at Mather's defense for Rowlandson's narrative publication:

This Narrative was penned by the Gentlewoman herself... Though this Gentlewomans modesty would not thrust it into the Press, yet her gratitude unto God made her not hardly persuadable to let it pass, that God might have his due glory and others benefit by it as well as herself. I hope by this time none will cast any reflection upon this Gentlewoman, on the score of this publication of her affliction and deliverance No serious spirit then (especially knowing anything of this Gentlewomans piety) can imagine but that the vows of God are upon her. Excuse her then if she comes thus into public, to pay those vows. Come and hear what she had to say (65-67).

The author of the preface frames the narrative for the "benefit" of readers in the name of God. And he clarifies that the woman author's writing and publication is just for the sacred reason of "paying those vows." On the one hand, Mary Rowlandson takes advantage of the status of both two big figures to ease potential declaims against her presumptuous act. On the other hand, more importantly, Increase Mather incidentally becomes the image speaker of Mary Rowlandson. In the preface, he repeatedly mentions that the author is a "Gentlewoman" with "modesty" and "piety." Her strategy enough proves that she knows how to kill two birds with one stone. Perhaps she has learned the lessons from Hutchinson, Mr. Hopkins' wife and Parker's sister.

The title page of little book is also worth the reader's attention. Rowlandson presents us an unprecedented lengthy one:

The Soveraignty and Goodness of GOD, Together With the Faithfulness of His Promises Displayed; Being a narrative of the captivity and restoration of Mrs. Mary Rowlandson, commended by her, to all that desires to know the Lord's doings to, and dealings with Her. Especially to her dear children and relations. Written by Her own hand and for Her private Use, and now made Public at the earnest Desire of some Friends, and for the benefit of the Afflicted. Deut. 32.39, See now that I, even I am he, and there is no God with me; I kill and I make alive, I wound and I heal, neither is there any can deliver out of my hand (62).

This page consists of three parts, with each framing her various virtues. As Steven Neuwirth writes, "The scope of the title has narrowed from the divine to the human, and the rhetoric has taken on a personal rather than a sermonic tone. In place of God's divine attributes, moreover, we are introduced to Mary's gifts and virtues" (Newwirth 1998:61). Apparently, Rowlandson is intended to present her faithfulness to God, her low profile, selflessness, and modesty.

\section{DECLARATION OF CHASTITY IN CAPTIVITY}

The concern of chastity is conceivably the foremost apprehension of Mary Rowlandson who had been kept in captivity. In the Puritan concept, women's chastity is undoubtedly the most important of all the female virtues. From the novel The Scarlet Letter, Nathaniel Hawthorn's masterpiece, the reader can get a grasp of the extremely strict Puritan view of chastity. In the story the protagonist Hester Prynne was disdained, rejected and exposed by the Puritan society because of her adulterous affair with the minister Dimmesdale. Her misconduct was thought to seriously violate the moral 
standards. As a consequence, she was cruelly punished. Although Rowlandson's experience has nothing to do with adultery, it is principally related to the same sensitive theme. Rape, like adultery, meant conviction of sin, even more disgraceful.

What is more, she was the wife of a Puritan minister. And her captors were uncivilized brutal Indians. Rowlandson was held captivity for almost three months, and during this period she stayed very close to her master and even met King Philip. She was still in her thirties, relatively young. Furthermore, "not only did the Puritans believe (wrongly) that Native Americans raped their female captives, their assumption was compounded by a published report that Rowlandson had been forced to marry the 'one-eyed sachem,' John Monoco, a Nashaway chief who led the raid on Lancaster" (Logan 1993:262-263). In the text Rowlandson does her utmost purposefully to clarify the speculations of rape and to testify to her sexual purity: "And I cannot but admire at the wonderful power and goodness of God to me, in that, thought I was gone from home, and met with all sorts of Indians, and those I had no knowledge of, and there being no Christian soul near me; yet not one of them offered the least imaginable miscarriage to me" (84). The main point which the narrator wants to make is the last sentence, namely, "yet not one of them offered the least imaginable miscarriage to me." According to the definition of the Oxford English Dictionary, the ambiguous word "miscarriage" also has the meaning of "misconduct" or "misbehavior." Clearly, Rowlandson tries to claim her physical innocence but with indistinct wording.

In the later course of her narration, Mary Rowlandson draws our attention to the subject of her chastity again. This time she expresses herself in a more direct way:

I have been in the midst of those roaring lions, and savage bears that feared neither God, nor man, nor the devil, by night and day, alone and in company, sleeping all sorts together, and yet not one of them ever offered me the least abuse of unchastity to me, in word or action. Though some are ready to say I speak it for my own credit; but I speak it in the presence of God, and to His Glory (107).

This passage is aimed to emphasize that her body still remains intact. Although she is encompassed with those Indian savages, in fact, nobody has violated her verbally or physically at all. The imagined perils of the "abuse of unchastity" to her do not exist at all. Moreover, "in the presence of God" she has a clear conscience. Rumors are just rumors. Speculations are just speculations. One more time she dispels the possible suspicion from her readers.

However, another interesting description of an episode between Rowlandson and her master Quinnapin makes us confused about the truth of her chastity. The scene in which a drunken sachem who is indulging himself in the victory chases her women and a Puritan female captive lets our imagination fly:

My master after he had his drink, quickly came ranting into the wigwam...and called for Mr. Hoar, drinking to him, and saying, He was a good man: and then again he would say, Hang him rogue: being almost drunk, he would drink to him, and yet presently say he should be hanged. Then he called for me. I trembled to hear him, yet I was fain to go to him, and so he drank to me, showing no incivility.... At last his squad ran out of the wigwam, and he after her, chasing her around the wigwam, with his money jingling at his knees: but she escaped him: but having an old squaw he ran to her: and so through the Lord's mercy, we were no more troubled that night (104).

Here Rowlanson vividly portrays her master as a lecherous "beast" in detail. She is for the first time stuck in a real “perilous" situation: After her master Quinnapin has already drunk too much alcohol, he especially calls for Rowlandson to drink with him. While the text implies that her master has "interest" in her, it indicates that he actually "shows no 
incivility" to her. In other words, maybe her master has the idea of raping her, but eventually he turns her attention to his squaws. In her explanation, it is "God's mercy" that helps her get away with the danger of being tarnished. Although she actively counters the circulated imputation on her chastity, what calls into question is if she is really sexually assaulted by her master or if she tries to cover up the fact of her misconduct, only to make it more conspicuous. Concerning this doubt, scholars express quite different opinions. For example, as Susan Howe suggests, "When she was Quannopin's slave, she liked her master, although she despised his wife, her mistress, Wettimore" (Howe 1993:100). Furthermore, Steven Neuwirth shows great interest in Rowlandson's ambivalence. He concludes, after decoding the two words "yet" and "fain" in the sentence "I trembled to hear him, yet I was fain to go to him," that Rowlandson is "in a liminal place, occupying the middle group between chastity and sexual adventure" (Neuwirth 1998:72). And Rebecca Blevins Faery points out that "her attachment to Quinnapin becomes intense in the course of the weeks she spends in his charge, and her frankness in expressing her closeness with him is striking" (Faery 1999:70). Nonetheless, this is a controversial issue. Undeniably Mary Rowlandson consistently spares no effort to uphold her foremost Puritan feminine virtue.

\section{RELIGIOUS PIETY}

Throughout the narrative, Mary Rowlandson depicts herself as a pious Puritan who overcomes trials and tribulations under the guidance of omnipotent God. According to Roy Harvey Pearce, the earliest captivity narratives are essentially "simple, direct religious documents" (Pearce 1947:2). In his view, the captivity narrative is for Puritans the "religious confessional" (ibid.1). Then Rowlandson's narrative is a typical religious record. Her story is divided into twenty removes in which she is forced to keep removing from one place to another with their captors in extremely harsh conditions. From being captured to being ransomed, it is more of her religious experience, which provides evidence for God's providence, grace, mercy, and salvation for her. Frequently she has recourse to the scriptures when she is in a difficult situation. Mentally and spiritually, she always tends to connect her situations with those analogous ones described in the Bible. God tests her, guides her, and offers her powerful spiritual strength. On the other hand, her miraculous survival indubitably justifies her faithfulness, patience, submission to God. In order to prove those virtues on her, Rowlandson employs the example of Goodwife Joslin.

Goodwife Joslin, who was one of her fellow captives, could not endure the wretched sufferings, thus harboring the intention of running away from the so-called beasts. And she even tried to instigate Rowlandson to escape with her. But she resolutely opposed such a rash idea considering the following adverse conditions: first, they were too far away from any English settlement and it was extremely cold; second, Joslin was a pregnant woman whose baby was due in one week and had another little child of her to take care of; third, there were still big rivers for them to cross, but they were already very "feeble". Instead Rowlandson wanted to calm down the desperate woman by sharing a scripture with her: "I pulled it out, and asked her whether she would read. We opened the Bible and lighted on Psal. 27 in which Psalm we especially took notice of that, ver. ult., 'Wait on the Lord, Be of good courage, and he shall strengthen thine Heart, wait I say on the Lord"' (77). The message is very clear: they should keep still, have patience and be courageous; if they stand up to the severe test, God will deliver them. But, unfortunately, Goodwife Joslin failed to abide by God' will:

Some of which I never saw afterward: the Lord only knows the end of them. Amongst them also was that poor woman before mentioned, who came to a sad end, as some of the company told me in my travel: she having much grief upon her spirit about her miserable condition, being so near her time, she would be often asking the Indians to let her go home; they not being willing to that, and yet vexed with her importunity, gathered a great company together about her and 
stripped her naked, and set her in the midst of them, and when they had sung and danced about her (in their hellish manner) as long as they pleased they knocked her on head, and the child in her arms with her (77-78).

The woman, who pestered her Indian captors repeatedly to release her, was ruthlessly humiliated, tortured and then killed by them, including her unborn baby and another child. Richard Adams, a Puritan clergyman, insists that “pregnancy constitutes 'an affliction,' a test imposed on women by God as the appropriate forum for their exercise of such Christian virtues as patience, submission and obedience. If pregnant women conduct themselves appropriately under the affliction of their condition, then 'the pains shall be sanctified, and be no obstacle to their welfare; their souls shall be safely delivered"” (cited in Thickstun 1988:11). Apparently Joslin's tragic fate results from her lack of those Christian virtues, which eventually arouses the wrath of God. In contrast to Joslin, Mary Rowlandson epitomizes a "Puritan Goodwife" who is nurtured to be patient, submissive and obedient. In the Puritan ethos women are edified to comply with the rule that they should submit to men's authority, because men stand for "Christ on earth and take the literal place of Christ as bridegroom to their earthly wives" (Davis 1992:54). In Rowlandson's opinion, Joslin should have submitted to her Indian captors. Hence, arguably Rowlandson highlights the aforementioned virtues which she possesses and her devoutness to God by contrasting herself with Joslin. At the very end of her entire story, she writes, "I have learned to look beyond present and smaller troubles, and to be quieted under them, as Moses said, Exod. 14. 13 Stand still and see the Salvation of the Lord" (112).

\section{A CAPABLE HOUSEWIFE}

Having shown the audience her femininity in the religious sense, in the eighth remove, Mary Rowlandson starts to establish her identity as an outstanding housewife. Such traditional female virtues as industriousness and capability as well as her shrewdness are best embodied in her mingling with King Philip, her master, her mistress and other squaws:

During my abode in this place, Philip spoke to me to make a shirt for his boy, which I did, for which he gave me a shilling: I offered the money to my master, but he bade me keep it: and with it I bought a piece of Horse flesh. Afterwards he asked me to make a Cap for his boy, for which he invited me to Dinner. I went, and he gave me a Pancake, about as big as two fingers; it was made of parched wheat, beaten, and fried in Bear's grease, but I thought I never tasted pleasanter meat in my life. There was a Squaw who spake to me to make a shirt for her Sannup, for which she gave me a piece of Bear. Another asked me to knit a pair of stockings, for which she gave me a quart of Pease: I boiled my Peas and Bear together, and invited my master and mistress to dinner (83).

Rowlandson's workmanship in knitting and sewing makes her highly favored by her captors during the captivity period. She is paid money or gets some food for her labor. She is also invited to dinner by his master. In return she invites him and her mistress to have dinner. While she makes the most of her housewifery skills to meet her basic needs of survival in such a disadvantaged environment, she takes advantage of the mutual interaction to ingratiate herself with her master and mistress. By offering her pay to her master, she shows her "loyalty" to him as a servant. It is perceptible that the aim of her tactic is to be accepted by and temporarily assimilated into the Indian circle. Only by doing this does she have the opportunity to live until redemption. Davis comments, "For Mary White Rowlandson the role of housewife becomes the controlling construct into which she fits her experiences and by which she governs her behavior as a captive because of its soteriological value, both spiritually and physically" (Davis 1992:55). Laurel Thatcher Ulrich demonstrates that "she knew how to please them. Growing up in a hierarchal society, she had learned what it meant to be an inferior" (Ulrich 1980:228). Laurel further argues that both her servility and her housewifery skills play a big role in her survived captivity. 
Rowlandson, as the writer and narrator, here succeeds in modeling her image of more than a conventional good housewife. Likewise, her capability, farsightedness, and shrewdness as a woman leave her readers a deep impression.

\section{CAPTIVE'S METAMORPHOSIS}

Mary Rowlandson' captivity experience witnesses her metamorphosis. Metamorphosis means, according to the English Dictionary, a striking change in appearance or character or circumstances. For Rowlandson, she enters from a civilized New England society to an uncultivated wilderness inhabited by those Indian "Barbarous Creatures." Meanwhile, her spirit and character undergoes a remarkable change, from being weak to being strong. At the beginning of her narrative, she writes, "I had often before this said, that if the Indians should come, I should choose rather to be killed by them than be taken alive, but when it came to the trial my mind changed; their glittering weapons so daunted my spirit, that I chose rather to go along with those ravenous Beasts than that moment to end my day" (70). She candidly tells us her inner fear of death. Then in the first remove she depicts her deep sense of loss and despair:

To add to the dolefulness of the former day, and the dismalness of the present night: my thoughts ran upon my losses and sad bereaved condition. All was gone, my husband gone (at least separated from me, he is in the Bay; and to add to my grief, the Indians told me they would kill him as he came homeward) my children gone, my relations and friends gone, our house and home and all our comforts within doors and without, all was gone (except my life), and I knew not but the next moment that might go too (71).

She was a minister's wife, a loving mother, a respected mistress, a respectable dame, but now she is reduced to a captive, a beggar, a servant, a slave. She had everything, but now she has nothing. She drops from the heaven to the hell. She is completely confounded and totally lost. That "All was gone" makes her spirit linger on the brink of collapse.

Mary Rowlandson, however, overcomes the difficulties, grief, and anguish. Finally she regains her freedom by paying a ransom of twenty pounds, and reunites with her husband and children. In 1682, six years after her release, she published her captivity narrative. Taking a look at the end of her book, we will know that the afflictions she suffered from have metamorphosed the weak, despondent woman from a captive into a sagacious woman whose spiritual state has been highly elevated: "I have seen the extreme vanity of this World: One hour I have been in health, and wealth, wanting nothing: But the next hour in sickness and wounds, and death, having nothing but sorrow and affliction" (111). Obviously, her narration shows that she has seen through some true essence of life. It dawns upon her that the truth of real life is not just joy and sweetness. Concerning her tribulations in captivity, Rowlandson expresses her great gratitude to God for His providence, mercy, and grace:

Affliction I wanted, and affliction I had, full measure (I thought), pressed down and running over. Yet I see, when God calls a person to anything, and through never so many difficulties, yet He is fully able to carry them through and make them see, and say they have been gainers thereby. And I hope I can say in some measure, as David did, "It is good for me that I have been afflicted." The Lord hath showed me the vanity of these outward things. That they are the Vanity of vanities, and vexation of spirit; that they are but a shadow, a blast, a bubble, and things of no continuance (112).

After living through the ordeal, the writer utters many words full of life philosophy. She attempts to share her comprehension for life from the innermost heart. By separating herself from the mundane world overwhelmed with "vanity of vanities," she self-fashions a great female image with wisdom, tenacity, and conviction. 


\section{CONCLUSIONS}

"Seeing themselves as different from other white women, captives do not therefore depict themselves as failures; rather, then relish how far they exceed the 'true woman's' purported abilities" (62), as Christopher Castiglia observes. Mary Rowlandson, "with the frame of Puritan conception" (Miller 256), not only narrates us her adventurous captivity experience, but also exemplifies as a female paragon of the highest virtues. She was very courageous to break the conventional rules and restrictions for women in the colonial time when women did not share most equal rights with men. Rowlandson is remembered as the woman writer who published the first captivity narrative in the early history of American literature. The article argues that in terms of literary artistry the uniqueness of her captivity narrative lies in the fusion of her female authorship and her way of shaping a great feminine image acknowledged in the Puritan community. In a nutshell, she represents a paragon of Puritan women, who survives the captivity by exerting her extraordinary virtues and merits.

\section{REFERENCES}

1. Breitwieser, Mitchell Robert. American Puritanism and the Defense of Mourning: Religion, Grief, and Ethnology in Mary White Rowlandson's Captivity Narrative. Madison: University of Wisconsin Press, 1990.

2. Castigilia, Christopher. Bound and Determined. Chicago \& London: University of Chicago Press, 1996.

3. Davis, Margaret H. “Mary White Rowlandson's Self-Fashioning as a Puritan Goodwife." Early American Literature 27 (1992): 49-60.

4. Dieblod, Robert K. A Critical Edition of Mrs. Mary Rowlandson's Captivity Narrative. Dissertation. Yale University, 1972.

5. Faery, Rebecca Blevins. Cartographies of Desire: Captivity, Race, and Sex in the Shaping of an American Nation. Norman: Univ. of Oklahoma Press, 1999.

6. Hawthorn, Nathaniel. The Scarlet Letter. Yugoslavia: Mladinska Knjiga-Ljubljana, 1966.

7. Hall, David D. ed. The Antinomian Controversy, 1636-1638: A Documentary History. Middletown, Connecticut: Wesleyan University Press, 1968.

8. Howe, Susan. "The Captivity and Restoration of Mrs. Mary Rowlandson," in Susan Howe, The Birth-Mark, Hannover and London: Wesleyan University Press, 1993. 89-130.

9. Logan, Lisa. “Mary Rowlandson's Captivity and the 'Place' of the Woman Subject.” Early American Literature 28.3 (1993), 255-277.

10. Merril D. Smith, ed. Sex and Sexuality in Early America. New York and London: New York University Press, 1998.

11. Miller, Perry, ed. The American Puritans: Their Prose and Poetry. New York: Anchor Books, 1956.

12. Neuwirth, Steven. "Her Master's Voice: Gender, Speech, and Gendered Speech in the Narrative of the Captivity of Mary White Rowlandson" in Merrill D. Smith, ed. Sex and Sexuality in Early America. New York: New York University Press, 1998. 55-86.

13. Pearce, Roy Harvey. “The Significances of the Captivity Narrative.” American Literature 29 (Mar. 1947): 1-20.

14. Salisbury, Neal, ed. The Sovereignty and Goodness of God, Together with the Faithfulness of His Promises Displayed: Being a Narrative of the Captivity and Restoration of Mrs. Mary Rowlandson and Related Documents. Boston: Bedford Books, 1997.

15. Thickstun, Margaret Olofson. Fictions of the Feminine: Puritan Doctrine and the Representation of Women. Ithaca and London: Cornell Univ. Press, 1988. 
16. Ulrich, Laurel Thatcher. Good Wives: Image and Reality in the LIVES OF Women in Northern New England, 1650-1750. New York: Oxford Univ. Press, 1980. 
